\title{
TEXTUALIZATION STRATEGIES, TYPOLOGICAL ATTEMPTS, DIGITAL DATABASES: WHAT IS THE FUTURE OF COMPARATIVE CHARM SCHOLARSHIP?
}

\author{
Emese Ilyefalvi \\ Eötvös Loránd University, Faculty of Humanities, Department of Folklore; \\ Hungarian Academy of Sciences, Institute of Ethnology \\ mseilyefalvi@gmail.com
}

In the article I present an overview of transformations in approaches to textualizing and typologizing folklore texts over the past 150 years using the example of incantations from anthologies to digital databases with a view to highlighting the new horizons digital databases can open up for research. In the first part of the article, I show how the textual characteristics of the incantation genre and the often implicit questions of researchers influenced the textological strategies of classic incantation editions. These primarily typological considerations largely determined subsequent potential interpretations. Using the dimensions of comparability established by Lauri Honko (phenomenology of tradition, the historicity of tradition, and ecology of tradition) I summarize recent attempts at classification by international folklore studies of charms pointing out the pitfalls and shortcomings of typologies as well as the fundamental incompatibility of the different typological conceptualizations. In the second part of the article, after briefly describing the responses of computational folkloristics to the textological, typological and comparatist problems of folklore texts I come to the conclusion that the elaboration of an international guide to textology, standardizing the textualization techniques of digital editions of incantations, would be more important for comparative studies than the creation of further national and international incantation catalogues. To this end and to generate discussion and debate I conclude with the outline of a set of possible multidimensional textological features to be taken into consideration in the creation of future digital databases of verbal charms.

Keywords: comparative methods, computational folkloristics, digital databases, digital editions, dimensions of comparability (Honko), international charm index, textualization of verbal charms, typology 


\section{INTRODUCTION}

Over the past fifteen to twenty years a renewed, international and interdisciplinary charm scholarship has emerged in Europe, the main motor of which is the Charms, Charmers and Charming Committee (hereafter: ChCh\&Ch) established in 2000 as part of the International Society for Folk Narrative Research (hereafter: ISFNR). Since 2003 researchers from across Europe, from Ireland to Hungary to Moscow, meet roughly on a yearly basis in order to discuss their most recent research results along various methodological and theoretical lines, in a comparative perspective and through the examination of national corpuses. The heightened interest can also be observed in terms of publications. In past years, charm collections were published in Europe by the dozen, from various historical ages from Antiquity to twentieth-century folklore collections. ${ }^{1}$ Since the text material is closely related to 'fashionable' topics of cultural history (religion and magic, witchcraft, etc.), besides folklorists, there are participants from various other fields (such as classical philology, history, linguistics, literature, anthropology, religious studies). Folklorists in a classical sense actually constitute a minority at these international meetings. Nevertheless, the ChCh\&Ch is a part of the ISFNR and one of its declared objectives - beyond having the researchers of verbal magic join forces - is to develop new methods for the structural and typological description of incantations and charms. These new strategies help the creation of national type catalogues that would eventually (and at last) culminate in the construction of an international charm index (Kuznetsova \& Toporkov 2012: 178). The meetings and publications proved to be fruitful in this field; however, an international charm index has yet to be developed; moreover, the mushrooming text editions and their textual processes are all different from one another, depending on who and where they are published. Although there have been numerous debates about this topic, ${ }^{2}$ propositions have even been put forward concerning the creation and the structure of a possible international charm index (Agapkina \& Toporkov 2013); their real applicability on an international level, in the present and the future is questionable.

Nevertheless, ChCh\&Ch has considered the creation of databases to be important from the beginning. Parallel to these efforts in 2005, the idea of the creation of a common, European verbal magic database arose within the framework of The Power of Words in Traditional European Cultures project led by Jacqueline Borsje (Borsje 2011). Nonetheless, currently, several national digital charm-databases are being developed (or have already been published) completely independently from one another: Mare Kõiva (Estonian), Jacqueline Borsje (medieval Dutch and medieval and modern Irish), Sanda Golopenţia (Romanian love charms), Aigars Lielbārdis (Latvian), Andrei Toporkov (Russian), 
and Éva Pócs \& Emese Ilyefalvi (Hungarian). This state of affairs is what has led me to write this paper, the will to move beyond these isolated approaches. There are a number of questions that charm scholars can engage with in order to join the lively and innovative discourse on digital folklore databases. ${ }^{3}$ What could computational folkloristics as a new branch of research contribute to understanding the phenomenon of verbal magic ${ }^{4}$ What distinctive problems does the genre of charms itself raise? What is the role of classical type indexes/ catalogues in this process? Is it necessary at all to have analogous type and motif indexes/catalogues in the age of digital databases? Is there any point in registering typologies in digital databases? If not, how can we incorporate and apply the knowledge accumulated by folklore and textual scholarship on the genre and on orality?

My goal in this article is to critically review the classification attempts of recent years, and based on this outline some criteria regarding the creation of a multidimensional digital textual database specifically developed for the genre of incantations and charms. These considerations might serve as an aid in the study of charms and what's more they might open up new paths of interpretation for researchers. I suggest that developing an international textological guide, proposing standards for the textualization practices of digitally edited charms would be a much more significant milestone than creating analogous national and international charm indexes. Although at first glance this might seem to be a merely practical and technical issue, I will also discuss briefly the novel theoretical and methodological problems textualization practices based on databases give rise to, which should be considered carefully before proceeding to digitization.

\section{THE RELATIONSHIP OF FOLKLORISTIC TEXTUALIZATION AND TYPOLOGIZATION}

Although the textualization of folklore texts has been one of the most elementary and most delicate issues since the beginning of the discipline, until recently it received very little conscious and reflexive attention from practitioners of the field. ${ }^{5}$ This might be partly due to the fact that the vital importance of textological work for interpretation processes only became broadly accepted in the last few decades (McGann 2014: 19-20). Broadly understood, folkloristic textualization involves more than merely taking down, transcribing, and annotating folklore texts. It also includes theoretical considerations before going to the field (what needs to be collected and how) and subsequently the selection and classification of texts, that is, the entire preparatory process for publication, are integral parts, including the theoretical and methodological preconceptions. ${ }^{6}$ 
In view of the above, the issue of typology is closely intertwined with various textual strategies, as documented by the fact (even within charm scholarship) that researchers interested in classification questions are almost exclusively those who assembled anthologies and text collections in the course of their scholarly careers (Holzmann 2001; Roper 2004; Vaitkevičienè 2008; Kljaus 2009; Agapkina \& Toporkov 2013; Pócs 2014b). Editors have to face the following questions in such cases: (1) How to classify the material? (2) How to resolve the problems resulting from the change of medium (oral to written; manuscript to print)? (3) What kind of annotation should the text be provided with? The answers to these questions are closely related to the characteristics of the genre being examined; therefore, before analysing charm typologies it is necessary to briefly discuss the most important textual features of verbal magic.

\section{TEXTUALIZATION PROBLEMS OF VERBAL MAGIC}

1. Since the beginning of charm scholarship there has been a consensus among folklorists that the majority of texts cannot be interpreted according to textual folklore criteria in a classical sense, that is, merely based on form and content, because the most important defining feature of the genre is function (Pócs 2014a: 14; Kljaus 2009: 71). A conspicuous editorial practice directly follows from this; namely, that to this day - unlike other folklore text collections - in charm research the editions based on function dominate (Roper 2004: 128-131). At the same time, the early recognition of 'function-text units' resulted in the consolidation of heterogeneous types in academic discourse; sometimes the text, at other times the function playing the dominant role. Another consequence of the function-centred definition of the genre is that published editions contain a diverse range of text material differing from one another depending on where the editor of the text drew the line (according to the given research tradition) between prayer, archaic prayer, blessing, curse, magic spell, ditty, etc. and incantations/charms. ${ }^{7}$

2. As regards verbal magic, another special textual characteristic that 99 (if not 100) per cent of the texts collected by folklorists are basically recounts and evocations. The private nature of the text material (usually one- or two-person acts involving: healer and patient), the various degrees of secrecy, furthermore fieldwork methods in early twentieth-century folklore scholarship did (and still do) not allow the observation of charm practices in a primary environment. ${ }^{8}$ This produces a pre-text (the charmer explains for the collector the rituals and gestures) before the actual charm text, which, in the primary context of application is presumably not present, or even if it is, it certainly is worded 
differently. Moreover, with evocations one might create texts that only imitate charm texts, and are not the actual retelling of a once pronounced text, rather a spontaneous improvisation invented by analogy with the text used earlier (Pócs 2014a: 17). This is somewhat inconsistent with the fact that there exist genuine charms that consist only of describing the charm activity, and these can also be the improvised texts of an actual charming event. ${ }^{9}$ For this very reason in many cases it is indeed difficult to draw the line between pre-text and charm texts. In most editorial practices the pre-texts are entirely missing, or only appear as an abbreviated summary by the editor; consequently they also play a lesser role in typologies and interpretations. Among more recent typological and interpretational propositions, however, several classifications consider the pre-text and the text as a 'magical scenario'/'charm plot' and treat them as a unit. ${ }^{10}$

3. Another distinctive textual feature of charms is that there are two simultaneous traditions, a written and an oral one, which are inseparable and, in many regards, separate at the same time. The dynamic relationship of the two media also provides countless intermediary, transient forms. ${ }^{11}$ While texts collected orally lack primary context, in the case of manuscript charm practices in a way the phenomenon can be examined in its primary context of application: that of the manuscript and the person using it. For this reason, instead of disintegrating the text of the manuscript and classifying the elements according to various criteria in many cases, editors of historical sources have undertaken the publication of entire manuscripts, basically applying the philological method of textual criticism in order to show the distinctive contexts of the different sources (Toporkov 2005, 2010; Timotin 2010; Ilyefalvi 2014b). Nevertheless, not treating written and oral traditions as dichotomous opposites should not erase the fundamental differences of the two traditions. Although written charms also exist in several philological variations, transposing directly the operating mechanism of the manuscripts' variability and diffusion (for instance: establishing stemmata etc.), to the oral tradition would be misleading (Honko 1986: 106-107; Honko 2000a: 6; Niles 2013a; Frog 2013: 20-21).

The list above could surely be continued, but perhaps this short overview already gives an idea of how charm researchers from various disciplines took into consideration the textual specificities of incantations (to varying extent and degrees), which unquestionably influenced editorial practices, classification attempts and, thus, possible interpretations. 


\section{DIMENSIONS OF COMPARISON: ATTEMPTS AT TYPOLOGY IN CHARM RESEARCH}

The textual characteristics of a text corpus may not be the only factors shaping the typologies; the (often implicit) research problems the resolution of which the typologies are created can also play a role in shaping them. Therefore, the question has to be raised: why do we need to classify folklore texts; what is the aim of typology? On the one hand, this is a trivial question: every typology holds the possibility of comparability in itself. On the other hand, comparison in folkloristics (as in related disciplines) leads to complex and intricate methodological and theoretical dilemmas, the detailed exploration of which cannot be pursued in this paper. ${ }^{12}$ Nevertheless, it is necessary to reflect on the fact - which by now qualifies as part of the history of the discipline - that the concepts of 'comparison' and 'typology' (with strongly negative connotations in some national folkloristics and, in some sense, in international folkloristics as well ${ }^{13}$ have been almost inseparably intertwined with the Historical-Geographic Method(s) that have defined the discipline for a long time. ${ }^{14}$ Often seen as if they were the only way of comparison, as if the Historical-Geographic Method(s) was//were) 'the' method of both folkloristics and 'the' comparative methods (Virtanen 1993). Although the historiographic reasons behind this stigmatization are clear, the problem of comparability is not unique to the Historical-Geographic Method(s). When discussing the issue of comparability, Lauri Honko emphasised the importance of distinguishing among types of comparison in order to see what type of mechanism, variability they are suited to analyse and interpret, and which characteristic of folklore phenomena can be captured by them (Honko 1986, 2000a, 2000b). Honko established three dimensions of comparison: (1) tradition-phenomenology; (2) tradition-history; (3) tradition-ecology (Honko 1986: 111-123). The typologies that charms studies have so far developed can be fitted into Honko's comparative dimensions quite easily. As a result, in what follows - without aiming to be exhaustive and only highlighting some classification concepts - I will discuss the various typological attempts of recent years within this framework.

1. The tradition-phenomenological dimension captures an aspect of comparison in which the phenomena under scrutiny are not genetically related to one another; but through their etic, phenomenological categories they are capable of outlining the universal character of human culture. They allow the capturing of fundamental similarities and differences, distinctive cultural processes and focal points. The exceedingly popular and simply functional charm typologies (such as: stopping bleeding, averting hailstorms, stopping headache, protecting against demons, love magic, etc.) belong to this dimension. The fact can 
be misleading that in a certain sense there are real written materials behind these functional categories, with their own, emic divisions since they follow the European Christian manuscript tradition where the authors of the manuscript recorded the texts serving various functions one after the other from a practical perspective. Nevertheless, extending the categories to texts collected from orality, and going beyond the cultural area of European Christianity, would be creating almost etic, mostly functionally classifying thematic units (such as healing charms, bewitching charms, stimulating charms, incantations stabilising social relationships). In fact, such classification of the texts only seems logical if one follows the literate, Christian, European intellectual tradition; thereby it is only suitable to formulate universals within certain limits (Sebeok 1974: 19).

The less popular kind of charm typology, involving the deep structural classification of texts, also contains the possibility of phenomenological comparison. Not surprisingly this aspect is applied mostly by those who study corpuses collected from oral traditions. In the case of such texts, basic grammatical and structural characteristics of the text material can be highlighted through the scrutiny of short and simple charm forms. Classification based on speech acts (wish, order, threat, dismissal, etc.), or grammatical structures (if, then...; so, as...; negation, opposition, comparison, enumeration, counting, etc.) brings to light the universal categories of magic and religion; their possible relationship to the transcendental world..$^{15}$

Among present charm classification efforts there have been two attempts to explore deep narrative grammar. When examining the charms of Eastern Slavs, Russian literary scholar Vladimir Kljaus resorted to the theory of 'folkloric plot', a common approach in Russian folklore studies usually applied to longer, narrative text materials. He classified the texts according to 'plot themes', the typologies of which could be composed of the combination of the following three components: action, the subject of the action (personage) and the place of the action (Kljaus 2009: 72). According to Kljaus, all kinds of charms fit into this model. The Lithuanian folklorist Daiva Vaitkevičienè took Kljaus's concept as her point of departure, however, since in most cases the Lithuanian texts did not develop into the above-mentioned three-component narrative plot, the author classified Lithuanian charms on the basis of the 'narrative function', how healing charms are supposed to work. With this she is, in fact, shifting the emphasis from the text to the belief content underlying the ritual, thereby defining deep structural categories such as 'separation-connection, expulsion, transmission, reciprocation, purification, destruction, locomotion-cessation, designation, redemption' (Vaitkevičienè 2008: 78-86). Vaitkevičienë's classification is perfectly applicable to the exploration of cultural frameworks and conceptual systems behind the texts within a given culture. 
2. National and international catalogues and indexes prepared according to Historical-Geographic Method(s) can be placed in the tradition-historical dimension on account of their method of comparison. In the classical-type monographs, motif indexes seek to render the historic nature, diffusion in time and space of each imagined text type, by pointing out cultural borrowings and various cultural impacts, along with their respective directions. The ChCh\&Ch's desire for an international charm index self-consciously positions itself within this comparative paradigm, since the international folktale catalogue by AarneThompson is considered to be the highpoint of the approach, a well-trodden 'tested path' and an example to be followed (Roper 2004; Agapkina \& Toporkov 2013: 86). Jonathan Roper's commentary claiming that we are not any closer to the goal than Ebermann was in 1903 suggests that we are trying to make up for a lack that arose more than a century ago (Roper 2004: 129. Cf. Ebermann 1903). Consequently, followers committed to this approach do not want to deviate from the typological tradition established in charm-research under the impact of the Historical-Geographic Method(s) in the first half of the twentieth century. Although occasionally even they are skeptical as regards execution, ${ }^{16}$ they consider the creation of an international charm index feasible when it is the result of the combined efforts of the experts of the ChCh\&Ch. ${ }^{17}$

The greatest problem with this approach, however, is what the critics of the Historical-Geographic Method(s) have formulated already: the types are rigid, arbitrary, artificial categories of research; their boundaries are uncertain and might vary by researcher, or even within the work of a single researcher. How do we define a type? Where do we draw the boundaries of a type? ${ }^{18}$ Roper and Agapkina \& Toporkov avoid answering these questions, and despite being aware of their omission, they fail to define in their writings the basis of the typology, what the constitutive and optional components of a type are. Typological problems are well known in folklore studies: ${ }^{19}$ nevertheless, let us consider a few concrete examples as illustration. One of the best-known medieval, western European incantations usually applied for stopping bleeding is the LonginusSegen. ${ }^{20}$ So far, there is only a single Hungarian text from the mid-sixteenth century, which served to heal heartache (Hattyuffy 1891). Besides this, there are two further variants of the text published in the most recent Hungarian edition of charms containing approximately 3500 texts (and referencing a further 5000 variants); ${ }^{21}$ or more precisely, there are two texts that can be connected to the Longinus charm, although neither of them were used for stopping bleeding (Pócs 2014b: 923). One of them is a twentieth-century text collected from oral tradition (but according to Éva Pócs, the origin is a manuscript remedy book), which alludes to the apocryphal story of Longinus, but does not name the soldier who pierced the side of Jesus on the cross. The other text coming from a 
seventeenth-century remedy book from a noble family, does use the apocryphal story and Longinus is also mentioned by name, but the charm was not meant to stop bleeding. The blood and water from Jesus's heart is only attributed a healing property for sharp chest pain (Ilyefalvi 2014b: 106). If there existed an international charm index, would these two texts belong to the Longinus-Segen type? A similar problem is raised by the fact that the Flum Jordan charm-type ${ }^{22}$ is completely missing from the Hungarian material, while the motifs of the River Jordan and the baptism of Christ can be found in numerous Hungarian narrative healing charms. ${ }^{23}$

The charm type and its artificial boundary fail in the case of book-based typologies when the classifying scholar is forced to assign it a place somewhere within a national corpus when in fact it could fit into several different types. ${ }^{24}$ In Éva Pócs's Hungarian charm typology we also find innumerable examples of how the dynamic text tradition resists classification. From this perspective, it is very questionable whether there is in fact a similarity between texts classified next to one another in the different typologies. To illustrate this problem let us see an example of an uncertain classification. In the Hungarian charm corpus, Éva Pócs refers to more than 500 texts which allude one way or another to the following narrative: Jesus looks for shelter on Earth (sometimes accompanied by Saint Peter, sometimes alone) and goes to a 'gentle/disobedient' master and an 'angry/obedient' mistress where he is only given a bed of wattle and a pillow of stone for the night. Jesus retaliates for the lukewarm welcome, by bewitching the angry/obedient woman's breast. Later Jesus heals her (in some versions at Saint Peter's request) with an incantation, and his text often includes the motif of 'bed of wattle, pillow of stone'. ${ }^{25}$ In the Hungarian classification the texts belong to a separate sub-type within narrative charms. (See examples in Appendix 1.) According to Éva Pócs, in some sense, they fit into the European group of encounter charms (Begegnungs-Segen) so termed by Ferdinand Ohrt, ${ }^{26}$ but by comparison with the latter, the plot of the story is rather unconventional and has much more in common with legends about Jesus/Saint Peter walking on the earth (Pócs 2014b: 895). The problem is not even the international classification of this text but the fact that this is not the only type of charm in the Hungarian corpus that contains the 'bed of wattle, pillow of stone' motif. There are numerous texts within the Hungarian material that do not provide the origin of the above described plot, only allude to the motif of 'bed of wattle, pillow of stone'. In certain texts this is minimalized to such an extent that the only part of the narrative plot we find is that "this is Jesus's word: bed of wattle, pillow of stone"; or even less, we only encounter distorted residues of Jesus's "word", used as a textual amulet (Pócs 2014b: 896). These texts were only placed in another group because they carried 'rather more' of the features 
of another type. (See examples in Appendix 2.) The same can often be said the other way around: the 'bed of wattle, pillow of stone' type examples could also be classified into other categories. The researcher using this kind of typology and the text edition cannot see these points of connection, except if they browse the collection of charms with extreme thoroughness and accuracy, or if they know the entire(!) corpus.

Since Roper and Agapkina \& Toporkov have not defined the basis of the types they use, they primarily operate with types that already exist in the research tradition. These are the 'well-known' western European charm-types so what do we gain by having them?27 Most of the main types established at the beginning of the twentieth century are healing texts which contain a narrative nucleus, a historiola. These charms are known from orality too - mostly through specialists -, but as regards their origin, they are parts of a written, Christian and Western European tradition. For this reason, the applicability of an international index based on a typological tradition that has no knowledge of Central and Eastern European charms is very narrow, even if we only wish to sketch the European and Christian tradition. Approximately 900 texts belong to the category of narrative charms from the more than 3500 texts published in the most recent anthology of Hungarian charms. From these 900 texts only a few hundred can be classified as one of the 'well-known' Western European types. If we take into consideration the variants in this ratio, then only 10-20 per cent of Hungarian incantations and charms can be classified within the deeply rooted Western European typological tradition. The ratios illustrate well the limits of the applicability of currently known and accepted types.

The tradition-historical dimension is undoubtedly an important and necessary perspective for discovering and understanding folklore phenomena. The research questions explored by Historical-Geographic Method(s) are in many cases legitimate and unanswered even today; these methods can be used for many kinds of investigation. ${ }^{28}$ However, it is less certain that the most efficient 'tool' for this comparative method would be an international charm index modelled on the international folktale catalogue by Aarne-Thompson (AaTh) or by Aarne-Thompson-Uther (ATU).

Lauri Honko claims that both 'tradition-phenomenology' and 'traditionhistory' compare and interpret phenomena from an intercultural perspective. They do so with data taken out of their contexts, therefore the connections are only seen by the researcher(s); they have no organic, active connection to the social functions and the variability of folklore phenomena.

3. Meanwhile, the comparative dimension called 'tradition-ecology' is suitable for discovering and understanding intracultural variability/traditions, which, unlike the former two aspects, has an active connection to the practices of a smaller 
or larger community (Honko 2000b: 15). This type of comparison examines three aspects, "the tradition itself, the community maintaining it, and the natural environment embracing them both" (Honko 1986: 116), in order to uncover a system in which the traditions function, and that it would later transmit. This method requires the study of 'thick corpuses', which are capable of revealing the organic functioning of the folklore phenomena in question. Although Honko envisioned the application of this dimension to corpuses recorded over the course of long-term fieldwork using participant observation, it might be used for the thick interpretation of certain archival materials; ${ }^{29}$ therefore I will illustrate this dimension with two historical examples from charms research. From the perspective of discourse analysis and cognitive theory, Anna-Leena Siikala, in her research on Eastern Finnish and Karelian incantations explores the limits of improvisation and, in this context, the 'scheme/frame' of incantations. Her main question was how charm specialists created their own texts by applying traditional motifs, lines, topics; whether the text followed any logic or whether it was a matter of completely free improvisation? Siikala needed this approach because the rich text variations of Eastern Finnish and Karelian incantations and the mode of their variation were impossible to explain by the catalogues and indexes of the Historical-Geographic Method (which, on the other hand, proved to be viable in the case of Western Finnish texts). Her analysis concluded that the textual patterns of incantations followed the structure of the incantation's ritual; and although the charmer was not mechanically repeating but creating the text in the given situation, the improvisation was still not free. It followed the logic of mythical thinking and thereby the text variations and the mode of variation could be interpreted within this mythical association framework (Siikala 1986).

Lea T. Olsan, scholar of medieval English literature, studied a completely different kind of source (two fifteenth-century English and Latin manuscripts) and applied a different theoretical perspective (mostly relying on psychological studies of memory) reinterpreting the problem of function-text unity that has always played an important role in the study of charms. Olsan's question was how and why certain motifs and text panels are (or can be) assigned to a certain need (such as stopping bleeding)? She approached the issue from the perspective of the person copying-using the manuscripts, in other words, of those who practice charms. With the study of 'semantic chains' she was able to demonstrate that what we have here is not the ad hoc use of texts for various needs. Rather, in many cases the chain had been broken such a long time ago that the association field is very difficult to decipher (Olsan 2004).

Clearly the intracultural perspective does not aspire to create an international charm index. Rather, on the one hand, through the examination of their 
own, more limited material, they point out the limitations of classical typologies, that is to say, that they cannot answer the questions the researcher is seeking answers to; on the other hand, with their innovative typological insights they discover connections that bring us closer to an in-depth, "emic" understanding of the cultural practice of verbal magic.

At the end of this overview the reader can no doubt see that even the author of this study could not resist the fundamental human urge to classify the phenomena under examination, in this case, the various charm typologies. My aim with this short review was simply to show the incompatibility of existing typological concepts. It should be noted though that the more ambitious charm typologies try to accomplish the impossible with the inclusion of various indexes and seek to navigate between at least two dimensions (for example, the tradition-phenomenology with function indexes and the tradition-history with the classification of types). The multidimensional catalogue by Éva Pócs systemising the corpus of Hungarian charms basically tries to alloy these two dimensions (Pócs 2014a, 2014b). Pócs begins the definition of charm-types with grammatical structures; she goes from simple forms towards more complex ones while noting the most typical contaminations of these forms. Nonetheless, she discusses and classifies narrative charms in a separate chapter, which takes them out of the logical context of the typology; but, in the introduction to narrative charm texts, she also describes their structural-grammatical features. One can search according to the function of the charm in the index at the end of the book; and at the same time, if certain types are characterized by a close function-text relationship, their description also figures in the introduction, as well as the related rituals and underlying belief contents. She also tries to include the tradition-ecological dimension wherever she can do so on the basis of her own field experience or of thick descriptions and corpus by others. Navigation, however, is not guided by the typology, but by the very informative summary of the introductory studies written in light of the approximately 8000 (!) texts. In this overview, Éva Pócs demonstrates the affiliation of various types with each other; the motivic or structural networks connecting a type to other types; the diverse or uniform combination of rituals associated with certain types; and the belief contents acting as the motor of these texts.

According to Lauri Honko, we need all three dimensions for a complex understanding of orality and folklore phenomena (Honko 2000a: 15-35). With what procedures, methods and tools can we achieve this? What comes after the three major textual paradigms of folklore studies: (1) when form did not matter, only the content: "pre-text"; (2) when only the text was at the centre of research: "text is king"; (3) when performance and context stands above all: 
"performance is king"? ${ }^{30}$ According to computational folkloristics, the only thing left is: "data(base) is king"!

\section{COMPUTATIONAL FOLKLORISTICS: DIGITAL DATABASES AS}

\section{A NEW TEXTUALIZATION PARADIGM}

Folkloristics has undoubtedly arrived at a new paradigm with the possibility of digital textual scholarship. Although folklore studies have already produced innumerable attempts and a prolific literature on this topic, it is still at an early stage in terms of theories and methodology. ${ }^{31}$ The truly tangible results of computational folkloristics have only began to appear in recent years. ${ }^{32}$ In what follows, from among the many attempts, theoretical and methodological considerations, I will only reflect on issues closely related to the main focus of my study, such as textualization practices, concepts of typologising, and comparability.

In the first half of the article I briefly discussed how important textualization practices as primary explanatory processes were in the typologisation as well as interpretation of charms. This has to be taken into account in the case of digital textualization as well; however, there are two fundamental differences between analogous (for instance: a critical edition's) and digital (for instance: a scholarly database's) textual processes. The first is that in the case of digital databases the (attainable) goal of textualization is to render the data analysable not only for the human mind but also for computer programs. Thus, the assemblage of data can also be interpreted by computer programs and not only by the scholars. (The advantages and consequences of this in folkloristics, as in any other field of digital humanities, are unforeseeable at this time.) The second fundamental difference, related to the first, is that while in the case of a critical edition we find that textual processes depend greatly on the scholarly background, interests and objectives of the editor(s), digital textual scholarship wishes to integrate the accumulated knowledge and the questions of a variety of earlier paradigms (Tangherlini 2016: 66). Consequently, the focus of the latter is not a single research problem; it does not have to choose, for instance, among the comparative dimensions of tradition-phenomenology/-history/-ecology. The aim is, in fact, to be able to provide answers to more diverse research questions by executing multidimensional textual processes on the text material, and subsequently presenting these texts/data in the form of a multimodal network. Naturally, digital textual scholarship is not devoid of preconceptions, ideologies and institutions either. ${ }^{33}$ It is especially for this reason that it is important for folklore studies to review and establish their digital textual strategies taking 
into consideration the most recent textual practices and cooperating with practitioners of related disciplinary fields (such as linguistics, literature, library science, etc.).

How can comparative dimensions be realized in digital databases, and what textual processes are required for this? It transpires from the above that the central problem and one of the most important criteria of digital textual processes is to produce computer-readable texts in order to be able to analyse them. For the textualization problems outlined in the first part of this paper to remain traceable in a folklore database, the method of text input has to be carefully monitored; otherwise the texts at the disposal of the programs will be simplified versions, which will result in more loss than gain. Creating computer-readable texts is the most expensive and time-consuming part of the digitization process, however, this is the part where the most important issues are decided. Selecting the longest lasting and most compatible file format (in order to ensure interoperability and comparability) is a fundamental criterion. ${ }^{34}$ After deciding on the technical aspects of text input, the second most important task is investing the text with as many kinds of metadata as possible. What external, yet closely related essential data do we want to record with a given text? Due to the existence of many different approaches within digital humanities this is the part where the greatest disparities might occur. A folklore-centered digital text edition requires quite different types of metadata than editions with a linguistic or literary history focus. The basic metadata for folklore databases, for instance, are as follows: location/time of collection; name of collector; name, sex, religion, language, nationality, occupation, etc. of informant. ${ }^{35}$ According to the logic of the Historical-Geographic Method(s), the typological classification of texts would also constitute such external metadata. Is it necessary, though, to record the type as metadata? How do existing folklore databases use international catalogues and motif indexes, the heritage of Historical-Geographic Method(s) in a wider sense?

Folktale research, due to its privileged situation (since it already has several international catalogues), continues to be in a pioneering role in testing and formulating new folkloristic methods and procedures. For understandable reasons, several of the folktale databases with scholarly requirements have adapted the AaTh and the ATU type numbers. ${ }^{36}$ Why should a relatively useful scholarly achievement be neglected, set aside or left out if it is a great reservoir of information and if it had inspired and oriented hundreds of researchers and thousands of works? Moreover, automatisms have already been developed to determine international folktale types, therefore it would not necessarily be a manual classification; the programs would take care of the laborious, often mechanical work (Muiser \& Theune \& Meder 2012; Meder 2014). Nonetheless, 
the more than two decade-long efforts of Theo Meder and his colleagues to digitize Dutch folktales raise at least three questions regarding the applicability of motif indexes and type catalogues. (1) Of the database currently containing more than 42000 texts, they were able to classify into folktale-types only about 60 per cent, despite having used not only the AaTh and ATU catalogues, but even other typologies. (2) The primary goal of the Dutch database is to become an instrument of international comparative research. In order to achieve this aim, however, (seeing that the catalogues were not helpful enough) they have taken a new approach. Currently, with the FACT (Folktale as Classifiable Texts) project their investigations concentrate on the development of computational processes that are able to show the narratives that contain motifs, sequences and other narrative building blocks, which help the programs to conduct automatic cluster analysis (Meder \& Karsdorp \& Nguyen \& Theune \& Trieschnigg \& Muiser 2016: 79). (3) Going beyond the problem of folktale databases in a narrow sense, it seems that there is a greater need for the creation of legend databases or aggregate databases containing folk narratives and integrating several genres (personal story, legend, folktale, belief narrative, etc.) (Meder 2014: 126; Meder \& Karsdorp \& Nguyen \& Theune \& Trieschnigg \& Muiser 2016). Leaving the rigid boundaries of genres behind, typologies play even less of a role in these databases. ${ }^{37}$ What is the solution then if there is no available and accepted typology? How can the corpuses become comparable and internationally interoperable if there are no types?

I have shown in the first part of the article in relation to analogous text editions that comparability is partly determined by textual strategies, which is also true in the case of digital databases. As regards digital textualization, the corpuses become comparable from a variety of points of view due to the metadata. The greater the number and variety of metadata included in the database, the more diverse and complex the analysis can be. A part of the external metadata has to be recorded manually during the textual processes (name of the collector, location of collection, type of source, etc.); however, whenever possible, one should seek automation, since manual annotation is not only time consuming and costly, but also the risk of error is very high, from simple typos to the fact that, given their human nature, different persons carrying out the annotation (might) have different ways of annotation. ${ }^{38}$

Finding similar textual parts can be achieved through further annotation of the texts recorded in the database. There are two ways to do so in the databases in the field of digital humanities: (1) supervised semi-automatic annotation or (2) unsupervised automatic annotation. ${ }^{39}$ For the former it is necessary to be aware of earlier folkloristic paradigms, structural and typological concepts regarding folklore texts and genres. This is important because semi-automatic 
annotation requires the accumulation of the features and elements from which researchers had developed the various types earlier. At the same time, the second method, proposed here, does not aim at creating types, since it is not our intention to squeeze the dynamic text tradition into prefabricated, artificial etic categories. We only indicate the simple characteristics that are considered to be the fundamental, inner, essential elements of the texts. The frequency and diversity of the network connection points among the different characteristics will be revealed by computational programs through various visual displays of the data. Thus, in this procedure it is still the researchers who determine what they want to get annotated with automations in order to connect the data with one another, this is what they target with various algorithmic procedures.

In the field of digital humanities, however, it is still debated what is worth annotating (McGann 2016); what is more, it is even questioned whether there is any sense in annotating at all, because if everyone has different annotating practices then the corpuses will be dissociated from one another. Another argument against annotation is that even this controlled indexing process is laborious and expensive; moreover, the real research only begins after the annotation is completed. Martin Wynne, an expert in digital humanities at the University of Oxford, argues that in these cases, instead of the interpretation of the actual data, we are focusing on future possibilities of interpretation; and this can only be avoided if we work on the development of better and faster instruments necessary for a completely automated annotation instead (Wynne 2012). In this case, the programs execute the indexing process on the corpus through various algorithmic procedures (using frequency and other statistical data, running a stemming and keyword generating software and other text mining methods) (see Jockers \& Underwood 2016). Based on efforts seen so far in computational folkloristics, it appears that for the sake of more complete analyses both are necessary (Abello \& Broadwell \& Tangherlini 2012). Although there is a lot of debate around annotation, it is clear that real interoperability among corpuses can only be achieved if the makers and the designers of the database annotate the same metadata and if these markups are recorded in similar, or at least compatible, systems. ${ }^{40}$ This would also eliminate another persistent issue of comparative research in folklore studies, namely that it would no longer be necessary to translate national corpuses into a common language (for instance, into English), because the programs would find the similarities and connection points without translation, on the basis of the markups. International standards in folklore studies are yet to be developed, although several authors have recently pointed out their necessity. In addition, at the 2015 meeting of the SIEF Working Group on Archives in Zagreb the plan of a 
guideline that would standardise the recording of metadata and annotations in folklore databases was also suggested. ${ }^{41}$

It is clear from the above that we are only at the beginning of a process; nonetheless, its significance can already be seen as regards the dimension of comparison/comparability. Unlike rigid type catalogues computational folkloristics with digital textualization and automatic and controlled annotation holds out the possibility that instead of imposing our own pre-fabricated categories on the dynamic folklore materials, instead of the researcher deciding what is similar to what, it will rather be computer programs that will process appropriately textualized data which in turn will bring to light the complex and complicated network of relationships between texts. The multifarious and innovative visualisations of the material's latent connections, not readily noticeable without computer programs, will allow us to pose brand new questions. ${ }^{42}$ Therefore, the buzzwords of computational folkloristics will replace linear structures, hierarchical unidirectional typologies and classifications with flexible, multimodal networks, graph and hypergraph systems, which will ensure easy navigation among its connection points (Abello \& Broadwell \& Tangherlini 2012: 65-66; Holger \& Schering \& Schmitt 2014: 72-83). The leading figures of digital humanities, and, thus, of computational folkloristics, claim that this will fundamentally change and (possibly) rewrite our concepts and understanding of similarities, of how and in what way things (for instance, folklore texts) can be similar to each other (Tangherlini 2016: 7; Meder 2014: 126). This opens up the possibility of a new dimension of research in addition to the existing comparative dimensions.

\section{DIGITAL CHARM DATABASES}

In the study of charms two databases have been developed thus far which are accessible for research. I will present both of them. I will start with the database of Sanda Golopenţia classifying Romanian love charms, then will continue with the international verbal magic database project of Jacqueline Borsje and discuss how they were able to make use of the above outlined opportunities (Golopenţia 1997; Borsje 2011).

Sanda Golopenţia, a researcher working in the USA studying francophone linguistics and literature, published a Romanian Love Charm Database on the internet. ${ }^{43}$ This relatively early initiative offers interesting lessons for future research (the database has been available on the Brown University's website since 2004). The database contains only 119 Romanian texts on the basis of the bilingual, Romanian-English charm collection edited by Golopenţia (Golopenţia 1998). One can clearly see that it is a very small corpus, which, due to its size, 
precludes any spectacular result. The texts, techniques (that is, the ritual), the frequency of the ritual's repetition, certain formulae, and cases where the charm did not come directly from the informant but from a second-hand description, were registered and annotated separately in the database in XML file format. ${ }^{44}$ The database can be searched according to speech acts, magical actions, magical adversaries (devil, the supernatural in general, witch, animal, human, etc.), magical aids, magical objects, magical plants, magical substances, the informant, the function, the region and the language. It is a great disadvantage that there are no complex search options within the database, the visualisation of the data is very rudimentary, and although it presents the material from several aspects with the help of the above-listed search options, these are actually external categories created to match the personal interests of Golopentia.

Jacqueline Borsje is a religious studies scholar at the University of Amsterdam; she introduced her database of European verbal magic in a 2011 paper, she developed it from her own field of research (medieval Dutch and medieval and modern Irish charms) but envisioned its extension to an international level. Borsje primarily called attention to problems caused by changing the medium (reality $\rightarrow$ manuscript $\rightarrow$ printed text $\rightarrow$ digital environment); in other words, she focused on showing the textual processes. She underlined the importance of the manuscript's context and the position of the charm in question within the manuscript containing it (marginalia, last page, etc.); this is why she encouraged the inclusion of the photos of the manuscripts. She also pointed out that earlier editions often 'upgraded' or 'supplemented' the texts, as a result, there are manuscripts that have different print versions, moreover, the original manuscript might not even be available for research (Borsje 2011: 131). This is not only a problem when entering medieval/early modern manuscript data into a digital database, the nineteenth- and early-twentieth-century text material of most folklore archives (including charm texts) also has several manuscript and print versions. ${ }^{45}$ This cannot be overwritten by a scholarly database; on the contrary, it is an explicit requirement that the persons using the database should be aware of the diverse textualization phases of the text they are looking at. While in the case of previous textualization paradigms, folklorists tried to hide their metadiscursive practices (Briggs 1993), one of the declared objectives of digital scholarly databases is to discover these practices, since it is indispensable information for the interpretation of the data. Borsje laid great emphasis on the accuracy and the method of text input; however, she was less interested in folkloristic aspects; consequently, her initiative can rather be considered as a common, digital working surface, than a folkloristic database. Although the cooperation and networking among researchers in a virtual research environment would undoubtedly yield significant results, Borsje's digital surface does 
not exploit the real potential of digital databases. Comparability, for instance, would only be ensured by having access to the English sample material of certain national texts through a common platform (Borsje 2011).

\section{SUGGESTIONS FOR POSSIBLE TEXTUAL GUIDELINES FOR DIGITAL CHARM DATABASES}

Drawing upon the above-described initiatives, in the remainder of the article, I will present some suggestions for the realization of possible textual guidelines for digital charm databases (focusing on metadata and annotation). For the time being, this is only a possible project; hopefully a future professional dialogue can result in the creation of a set of actual guidelines that would help synchronise the efforts of researchers working on the digitization of charms, in the hope that the databases would be able to simultaneously realise the different dimensions of comparability. Although this article discusses textual scholarship, typology and comparability especially in relation to charms, its most important message can be applicable to digital textualization dilemmas of other folklore texts regardless of their genre. As I have previously underlined, creating aggregate databases is a much more important goal than arriving at a rigid division by genre. The Hungarian charm-database being developed within the framework of the "East-West" Research Group (Vernacular religion on the boundary of Eastern and Western Christianity: continuity, changes and interactions. ERC project No. 324214) is identical in its basic structure to the belief-text database, which is also in a preparatory phase; precisely so that later it should be possible to integrate one into the other. None of the metadata below are charm-specific, therefore they might in fact be almost mandatory for any folklore database: ${ }^{46}$

\section{List of basic metadata}

1. type of source (a. folklore collection, collection-manuscript b. marginalia, codex, witch-trial, notes of secular or religious authorities, letters, antisuperstition literature, household notebooks, treasure-hunting magical books, etc.)

2. name of collector/scribe

3. time and place of collection/recording

4. (age, language, religion, occupation, nationality, place of residence of) informant

5. language of the text (for example: Hungarian, Latin, Hungarian-Latin, Gibberish) 


\begin{tabular}{|ll|}
\hline 6. & location of text \\
\hline 7. & editions of text \\
\hline 8. & secondary literature \\
\hline
\end{tabular}

The real textological problems start after this, with the input of actual texts. Among the known folklore databases some carried out the digitization of a publication or publication series. ${ }^{47}$ In many cases there is no other way, since the field notes, previous clean copies, manuscripts, voice recordings, etc. are not available for research. While critical editions implicitly subject the texts to uniform textual processes, the scholarly databases incorporating various editions and manuscripts should not standardize them, or they risk making metadiscursive practices disappear even further. Therefore, one should not annihilate earlier textual procedures in databases; the texts must be uploaded to the letter and if there are more than one philological version of a text, they all have to be registered. In the case of pre-nineteenth-century texts, for instance, we have entered at least two philological versions into the Hungarian charmdatabase: the diplomatic transcription of the manuscript and the modernized, interpreted transcript.

That the text is the joint creation of the collector and the informant is well-known since the performative and contextualist turn of folklore studies during the 1970s. Similarly, we are aware that interpretation requires the given folklore text to be recorded with as much context as possible even if the text comes from an artificial collection situation. Nonetheless, the method of recording the context and the interaction is less obvious and constitutes a constant source of problems (Fine 1984: 95; Honko 2000a: 11-15). Although there are no restrictions concerning the size of a database, the editors still have to decide where to draw the line as regards the context of the texts. For the Hungarian charm-database we chose the solution of at least recording the direct linguistic 'co-text' of the texts if it was available. In the case of texts collected from oral tradition this 'co-text' meant the interview questions since it was not unimportant to know what the text was giving an answer to and the explanations, additions pronounced directly after the text. We applied the same process to manuscript sources. The wider context of the text was included in the comment section, for instance the circumstances, objectives and methods of collection, or the most important information about the manuscript, such as its short description and the charm's position within the manuscript. This is often a ritual instruction specifying how the text should be pronounced. The vernacular terminology of the text's co-text has to be standardized, regardless of whether it refers to a function, or explains what the given text was used for or the how the rite had to be executed. 
Carrying out the above-described metadata input and the semi-automatic annotation of the co-text represents immense progress as regards charms research: the perspective of the research can be quickly and easily changed, free from the pressure of decision-making imposed by book publications. One can rearrange the text material based on function/source/location at any moment. It will also be possible to formulate questions that used to be less conventional, that were practically absent in previous edition practices. For instance, to list and display on a map the texts in the database, which are accompanied by certain rituals (such as casting water or spitting), or to list the emic terminology of the text material, or to compare it with research categories. The option of posing complex research questions has to be ensured when developing the database.

Identifying the similarities among texts requires the previously described, additional annotation. The annotation list below was greatly inspired by the multidimensional typology created by Éva Pócs's for Hungarian charms, and by the typological and structural results of international charm research discussed in the first part of this article.

\section{List for advanced annotation}

1. Performativity - (speech acts): assertion, negation, request, coercion, command, curse, menace, scold, prayer, imploration, dismissal, counting, enumeration, etc.

2. Structural characteristics: comparison, opposition, impossible condition, chain structure, etc.

3. Narrative scene: plot, actors, function of actors in the plot (bewitcher healer - helper - mediator)

4. Canonical text (prayer, hymn, or fragments from them)

As regards the content of the text:

5. Places/locations: no man's land, mountain, river, forest, rock, Heaven, gates of Heaven, Hell, Nazareth, Paradise, River Jordan, holy garden, wilderness uninhabited by people, etc.

6. Plants: basil, hazel rod, etc.

7. Objects-elements: cross, holy candle, five wounds of Jesus etc.

8. Fixed formulae: "where no dogs bark", "where no bread is baked" etc.

9. Animals: dog, rooster etc.

10. Colors: red, black etc.

11. Numbers: 3, 7, 77, 9 etc. 
12. Time: Friday, Saturday, in the evening, in the morning etc.

13. The world turned upside down: taboo words

Each one of the above can be automated by the application of text-mining tools (standardization, lemmatization, stemming etc); therefore, one should not worry about the meticulous annotation of millions of texts, the programs have only to be taught to recognize and automatically index them. ${ }^{48}$ The new comparative dimension, the completely automated annotation can only be realized if a significant amount of text is uploaded to the database, therefore the results cannot yet be foreseen.

However, it is already clear that computational folkloristics with digital folklore databases offer a tool for novel and simple solutions to problems raised at the beginning of this article. With their help the dream of the HistoricalGeographic Method(s) might come true: the visual representation of millions of charm texts in space and time on a map; and all this without having to think in terms of the much-criticized rigid types or having to translate anything into a common language. The future integration of various databases and corpuses into one another (in the case of charms, for instance, prayers, religious chapbooks, belief-texts) will allow the creation of thick corpuses necessary for the in-depth interpretation of data.

\section{(IN LIEU OF) A CONCLUSION}

Synchronizing goals, procedures and techniques stemming from various types of grant funding, individual undertakings and institutional digitization projects might seem to be at least as utopian an idea and venture as the creation of an international charm index. Nevertheless, I think that discussing textualization strategies of folkloristics in the digital age is a primary and necessary task of the discipline, and, thus, of charm-research. At the beginning of the twentieth century - corresponding to the technical options of the age - an international type catalogue (AaTh) was able to catalyze research. Today, the same effect could be achieved in twenty-first-century folkloristics by developing textual guidelines through thorough consideration by a group of international experts (for instance the $\mathrm{ChCh \& Ch}$ ), leading to standardization of the procedures of digital text editing. For this reason, the list above is only an initial draft of features that seem relevant from a folkloristic and from a general textual point of view, and that in my view, should be examined when registering charms in a database.

The database in itself obviously does not solve all problems; ${ }^{49}$ the new technology, procedure and theory leaves at least as many problems and questions 
unanswered as it solves. All this, however, will be the problem of the coming paradigm. In the present a multidimensional, digital text preparation would open the gates to new interpretations and analyses, which would bring us closer to understanding the compound and complex phenomena of folklore texts, such as charms.

\section{APPENDIX 1. THE 'BED OF WATTLE, PILLOW OF STONE' SUB-TYPE}

\section{A. Mellfájás gyógyítása}

A beteg háromszor mondja:

Mikor Krisztus Urunk Szent Péterrel a fódön járt, möntek egy szögén embörhön, szállást kértek. A gazda ajálta, hogy ad, de az asszon ajálta is, nem is. Az asszony gyékényt terítött, és követ tött a feje alá. Jézus azé szépen nyugodott, Szen Pétör is. Ezután éccaka elkezdött [az asszonynak] a mellye fájni. Fókeltek korán. Jézus Pétörrel elmöntek. Mikó möntek ed darabon, aszondta Pétör: "Uram, Teremtôm! Gyógyítsd mög annak az asszonnak a mellyit! Látod, hogy egész éccaka jajgatott!” - "Nem, Pétör, hagy szenvedjön!” Mögén elmöntek ed darabon, aszondja Pétör: "Uram, Teremtóm! Gyógyítsd mög annak az asszonnak a mellyit! Látod, hogy egész éccaka jajgatott!" Akkor aszondta Jézus: “Pétör, eredj vissza. Mondjad néki:

Engödelmes gazda, engedetlen gazdasszon.

Gyékénágy, küpárna,

Isten mondta szó."

Azonnal mögtért a fájdalom.

Három Miatyánk, három Üdvözlégy. ${ }^{\mathbf{5 0}}$

\section{Curing breast-ache}

The patient says three times:

When our Lord Christ walked on the earth with St Peter they went in to a poor man's house, asking for shelter. The man was inclined to offer, but his wife was not so keen. The woman spread a mat on the floor and put a stone as a pillow. Jesus nevertheless fell asleep and so did St Peter. During the night the breast of the woman began to hurt. They got up early. Jesus left with Peter. When they had gone a little way, Peter said: "Lord, my Creator! Cure the breast of that woman! You see she screamed 
all night!" "No Peter, let her suffer!" They went on for a while, says Peter: "Lord, my Creator! Cure the breast of that woman!" You heard how she whimpered all night! Then Jesus said: "Go back Peter and tell them:

Obedient master, disobedient mistress, bed of wattle, pillow of stone, word of the Lord."

That very minute the pain stopped.

After this the patient repeats the Lord's prayer and the Hail Mary three times.

\section{B. Gyógyítás}

Istennek mondom parancsolatjábul, az te szent hatalmaddal, Szentháromság Úristen.

Elindula Urunk Jézus Krisztus egy zsidó városban, vete ônéki egy zsidó leány kóvánkost, gyékénylepedót, mint Urunk Jézus Krisztus nem maradhatott kôvánkoson, gyékénylepedôn,

úgy ne maradhasson keserves fájdalmad az csontjaid vagy más tagjaidban!

Azután pedig a Miatyánkat is el kell mondani. Anno 1752. die 3. Junii coram figura iuris praedeductam orationem recitavit, et quod contra morbos ea usa fuerit, fatebatur, tendebuit [---] licere super infirmam iam susurando, sed cupienti etiam clara voce recitavit. A genitrice didicit hanc orationem, qua [?]tta. ${ }^{51}$

\section{Healing}

I say this by the command of God, by your holy might, Lord God of the Holy Trinity.

Our Lord Jesus Christ set out in a Jewish town, and a Jewish maiden laid him a pillow of stone and a bed of wattle, just as our Lord Jesus Christ could not rest on a pillow of rock and a bed of wattle,

let this bitter pain likewise not find rest in your bones or other limbs. And then you need to say the Lord's Prayer. On June 3rd 1752, she recited the above quoted prayer in front of the court of law and related that it was used against disease and recommended it [---] to be spoken in a whisper over the sufferer, but for the curious she now also spoke it in a full voice. She had learnt this prayer from her mother, which [---] 


\section{Pokolvar ellen}

Mikor az Úrjézus itt ezen a földön járt, útazott.

Bemënt ëgy jámbor gazdáhon,

Haragos gazdasszonyhoz szállást kérni.

Adott néki szállást gyékényponyván mëg kôvánkoson.

Minthogy az Úr Jézus ezën a gyékényponyván és kóvánkoson helyit nem találta,

Úgy itt ez a fájdalmas pokolkelet pokolvar

Vagy akarmiféle támadás itt, ebben a testbe

Helyit në tanálja!

Mënjën lë a fód alá fájdalma!

Oszlassa el az Atyaisten!

Oszlassa el a Fiúisten!

Oszlassa el a Szentháromság Ëgyisten!

Mënjën lë a fód alá fájdalma! ${ }^{52}$

\section{Curing growths}

When the Lord Jesus walked and travelled on Earth, he went into the house of a gentle master, and of an angry mistress, to ask for shelter.

She gave him shelter on a bed of wattle and a pillow of stone.

Just as the Lord Jesus could find no place

on this bed of wattle and pillow of stone, so may this painful growth or any such kind of lump here

not find its place in this body!

May the pain go down under the ground!

May God the Father disperse it!

May God the Son disperse it!

May the one God of the Holy Trinity disperse it!

May the pain go underground!

\section{Kelés ellen}

Az Atyának, Fiúnak, Szentlélök Úristen nevibe körösztöllek sëmminek.

Gyékénykáka,

Kőpárnája,

Krisztusnak tüskös lepedóje,

Sajtalan kásája.

Krisztus mondása:

Múljon el a támadása!

Atyaisten, oszlasd el! 
Fiúisten, mulaszd el!

Szentlélek Úristen, vidd el ${ }^{53}$

\section{Against growths}

In the name of the Father, the Son and God the Holy Ghost I baptise you as nothing.

Bed of wattle, pillow of stone, a thorny sheet for Christ, and porridge with no salt.

Christ's word:

May this growth go away!

God the Father, disperse it!

God the Son, disperse it!

God the Holy Ghost, take it away!

\section{E. Imádkozás mellfájásra}

Kúpárna, gyékényágy,

Sajtalan kása.

Jóakaratú embör, Rossz szándékú asszony, Az Isten szava, mondása.

Ez lögyön a csöcsfájósok

Orvossága.

Valaki szállást kért. Aszonták, engedjék be éjszakára. Aszonta az asszony: nem kô, vagyunk itt ölegen. Në engedjük be! Ó, aszongya, hát majdcsak valahun macsarítunk neki ëgy kis helyet. Igazítsál ide. Tödd lë a gyékényt, oszt rá ëgy párnát vagy valamit. Osztán lëtött egy gyéként, osztán a feje alá ëgy téglát tött az embörnek. Aszt azé van ez az imádság. ${ }^{54}$

\section{Prayer for curing pain in the breasts}

Pillow of stone, bed of wattle, porridge with no salt.

A man of goodwill, a woman of ill intent.

This is God's word. May this be the remedy for people with pain in the breast. 
There was someone who asked for shelter. He asked to be let in for the night. The wife said, 'No, there is enough of us here. Let's not let him in!' 'Oh, we'll make some room for him somewhere. You listen to me! Put down the wattle mat and a pillow on it or something.' So she put down a mat of wattle and put a brick down to go under the man's head. So that's why we have this prayer.

\section{APPENDIX 2. "BED OF WATTLE, PILLOW OF STONE" MOTIF UNDER DIFFERENT CHARM-TYPES AND SUB-TYPES}

\section{Igézet gyógyítása}

[...] Szem megnézte, szív megigézte, ezer angyal látta, s ezer angyal jöjjön a megvigasztalására a kicsi Vérikének, hogy meg ne nyugudjék az igézet benne, mint az Úr Jézus Krisztus a gyékényágyon s a kốpárnán meg nem nyugudt!

Újra Miatyánk és Üdvözlégy, minden parázs bedobásakor. [...] $]^{55}$

\section{Curing "the evil eye"}

[...] Eyes had looked at her, heart had bewitched her, a thousand angels had seen her, may a thousand angels come and comfort little Vérike, so that the evil eye may find no rest in her, just as the Lord Jesus Christ could not find rest on the bed of wattle and the pillow of stone! Again Our Father and Hail Mary, while throwing in each ember. [...]

\section{Naming the perpetrator + wishes, commands, supplications, blessings, curses (curing the evil eye)}

11. Naming the perpetrators + supplication, blessing, reference: the Virgin Mary Typology according to Éva Pócs (Pócs 2014b: 691-708) 


\section{Ficam gyógyítása. Curing sprains}

\author{
Elindula Urunk Jézus \\ Jerikóból Jeruzsálembe. \\ Általmene kóhidon, \\ ô lován, ô szamarán. \\ Haragos gazdasszony, \\ jámbor gazdája, \\ gyékényágy, \\ kőpárnája, \\ kókenyere, \\ fakése, \\ ez az Isten mondása:
}

Our Lord Jesus Christ set out from Jericho to Jerusalem.

He went across a stone bridge on his horse, on his donkey.

An angry housewife, a gentle master, a bed of wattle, a pillow of stone, a bread of stone a wooden knife, this is God's saying:

“Ezen jószág semmi ízébe, tagjába

"In no part or joint of this animal ficemlés vagy nyílamlás meg ne maradhasson,

hús húshoz, should there be any sprain or twist left, csont csonthoz, flesh to flesh, tag taghoz, bone to bone, ín ínhoz, part to part, vér vérhöz, ér érhöz." vein to vein, Krisztus Jézusnak maga szájából származott szent igék által gyógyuljon meg! ${ }^{56}$

May she recover through holy words spoken by the very mouth of Jesus Christ.

\section{The stumbling horse/donkey (second charm of Merseburg)}

2. Jesus with the Virgin Mary - they do the healing

Typology according to Éva Pócs (Pócs 2014b: 709-793). 


\section{Szentantaltüze gyógyítása}

Elindult a szentantal

hét fiával, hét leányával, hetvenhétféle unokájával, tüzes orbáncos dagadott sebeivel, fene farkasaival, vad oroszlánjaival, hogy Jusztinának gyenge szüvit elszorítom, piros vérit ott megiszom.

Térj meg, szentantal, kérlek a Jézus Krisztus keserves kínszenvedéseire, öt mélységes sebeire, eredj el az erdókre, ott a vad oroszlányoknak gyenge szüviket szorítsd el, piros vérüket ott idd meg!

Térj meg, szentantal, vagy akármiféle eredet vagy! Mikor Krisztus a földön járt, hegyek nóttek, kövek tốttek, Krisztus mennybemenetele után mindenek megtértek, térj meg te is, akármiféle eredet vagy!

Az Úr Jézus Krisztusnak

gyékényágya,

kőpárnája, sütelen kása, fötelen pogácsa, ez a Krisztus Urunk vacsorája,

kérlek erre a keserves kínszenvedésekre, térj meg, akármiféle eredet vagy!

Édes Jézusom, nem az én akaratom szerint; miképpen mennyben, úgy legyen a födön!

Ha te akarod, mutasd meg a te irgalmasságodat, ne nézd búneinket, sok ellened való cselekedeteinket, édes Jézusom! [77 $^{57}$ 


\section{Curing St. Anthony's fire}

St. Anthony set out with his seven sons, and his seven daughters, seventy-seven kinds of grandchildren, his fiery, swollen erysipelas wounds, his terrible wolves, his wild lions, saying 'I'll squeeze out Jusztina's gentle heart, I'll drink her red blood'.

Turn around, St. Anthony, I beseech thee by the bitter sufferings of Jesus Christ, by his five deep wounds, go into the woods, squeeze the gentle hearts of the wild lions, drink their red blood! Turn around, St. Anthony, or whatever kind you might be! When Christ walked on Earth, here were mountains growing, there were rocks emerging, after Christ's ascent to heaven all people converted, you convert, too, whatever kind you are!

\section{The Lord Jesus Christ}

has a bed of wattle, a pillow of stone, raw grain

unbaked scones, this is our Lord Christ's supper,

I beseech you by all of these bitter sufferings, convert, whatever kind you may be!

Sweet Jesus, do not as I will, but just as it is in heaven, so be it on earth! If you choose to, please show your mercy, regard not our sins, our numerous actions against you, sweet Jesus!

\section{Encounters of sacred and evil figures (Begegnungssegen)}

1. The migration of the evil figure

Typology according to Éva Pócs (Pócs 2014b: 709-793). 


\section{AKNOWLEDGEMENTS}

The research leading to these results has received funding from the European Research Council under the European Union's Seventh Framework Programme (FP7/2007-2013) / ERC grant agreement No. 324214. Supported through the New National Excellence Program of the Ministry of Human Capacities.

\section{NOTES}

1 Few example: Golopenţia 1998; Agapkina \& Levskievskaja \& Toporkov 2003; Vaitkevičienè 2008; Kõiva 2011; Pócs 2014b. From historical sources: Lecouteux 1996; Braekman 1997; Holzmann, 2001; Bozóky 2003; Schulz 2003; Toporkov 2005, 2010; Timotin 2010; Ilyefalvi 2014b.

${ }^{2}$ http://isfnr.org/files/Responses_to_Toporkov_and_Agapkina.pdf

3 See for instance: Voigt 2006; Holger \& Schmitt \& Janssen \& Schering (eds.) 2014; Oral Tradition, 2013, 28(2) special edition of Archives, Databases, and Special Collections. http://journal.oraltradition.org/issues/list?id=59\#59

4 On the current state of computational folkloristics see Abello \& Broadwell \& Tangherlini 2012, and other programmatic studies by Timothy R. Tangherlini: Tangherlini 2013, 2016 and the special issue of the Journal of American Folklore: A Special Issue on Computational Folkloristics. JAF 2016: 129(511). http://muse.jhu.edu/issue/33349

5 Some important overviews and thought-provoking studies on the subject: Fine 1984; Briggs 1993; Foley 1997 [1995]; Gay 2000; Honko 2000a, 2000b; Barna 2003; Voigt 2004, 2006; Landgraf 2006; Niles 2013a, 2013b; Katajamäki \& Lukin 2013. The textual guideline of Hungarian folklore studies: Voigt \& Balogh 1974.

6 See Lauri Honko's (Honko 2000a: 17) overview about the factors of textualization.

7 Some consider the ditty about encouraging ladybirds to fly away to be such (Roper 2005), others mention them as being on the borderline between genres (Pócs 2014b), and there are also editions that publish even canonical prayers (Vaitkevičienè 2008). On the etic, artificial nature of separating prayer, archaic prayer and charms see most recently: Kapaló 2011a, 2011b: 190-191; Pócs 2014a: 14-18.

8 All this does not mean that some nineteenth-century folklorists would not have considered all this a problem, or would not have tried to get closer to the original context. See for instance: Stiùbhart's 2014 study on the charm-collecting journeys of the Scotsman Alexander Carmichael in the second half of the nineteenth century (Stiùbhart 2014). However, in general, it can be said that the editors of twentieth-century charm collections paid less attention to the description of the rituals connected to the texts, they rather concentrated on the text material. The methodological problem stemming from the difficulty of collecting charms in action still exists in the twenty-first century, for more on this cf. Takács 2015: 15. It is relatively rare, even in the case of longer fieldwork based on participant observation, to be present at the original act of the charm, unless the person is the one treated by the charmer. In relation to this cf. the anthropological fieldwork experiences of James A. Kapaló (Kapaló 2011b: 171-172). 
9 Cf. Pócs 2014a: 17, 39. Cf. also Lauri Honko's statement about the charmer never memorising and reiterating lines during the composition process (Honko 2000b: 24).

${ }^{10}$ In her pragmatic typology Sanda Golopenţia classifies the entire 'magical scenario'; similarly, Vladimir Kljaus considers the pre- and post-texts joining the concrete texts as parts of the 'charm plot' and builds his classification on the ensemble of these (cf. Golopenţia 2009; Kljaus 2009; Vaitkevičienè 2008).

${ }^{11}$ Pócs 2014a: 22-30; Ilyefalvi 2014a: 21-23. For the dialectics of the two traditions see the relevant studies in recently published collections of essays: Roper 2004, 2009; Kapaló \& Pócs \& Ryan 2014. Daiva Vaitkevičienè, however, points out in relation to the Lithuanian material that no manuscripts or chapbooks containing charms are known in Lithuania before the twentieth century (Vaitkevičienè 2008: 94).

${ }^{12}$ See the introductory study by Linda Dégh (Dégh 1986) and the studies of the Journal of Folklore Research's special 1986, 23(2/3) edition entitled "The Comparative Method in Folklore". See also Virtanen 1993; Wolf-Knuts 2000.

${ }^{13}$ Cf. Frog 2013: 18, 22; Katajamäki \& Lukin 2013: 9. At a roundtable discussion organised in Vilnius in 2013 at a congress of ISFNR with the title "Why Should Folklore Students Study "Dead" Legends?" underlined the importance of researching archival folklore material. The discussion also included the re-evaluation of Historical-Geographic Method(s) and the reinterpretation of the problems of archiving-typologizationcomparison from various national perspectives. See the entire discussion and the problem-raising presentation of Terry Gunnell (Gunnell et al. 2013).

${ }^{14}$ Frog pointed out in his study that, in some national folklore disciplines, there is incoherence in the use of the term 'Historical-Geographic Method'. The related methods do not constitute a uniform methodology, yet in some cases they used the term to refer to a certain methodology. In order to bypass these inconsistencies and to avoid misunderstandings, Frog introduced the term "Historical-Geographic Method(s)". In agreement with Frog, I will use this terminology throughout the study (Frog 2013: $19)$.

15 Sebeok 1974, also see the speech act-based categories of Gorovei, Artur: Descântecele românilor, Studiu de folklor (1931, Bucuresti: M. O. Imprimeria Nationala). Referenced by: Golopenţia 2004: 152.

${ }^{16}$ Jonathan Roper rather encourages the monographic presentation of certain types following the model of the charm entries in the Handwörterbuch des deutschen Aberglaubens (hereafter HwdA). However, he considers the main types identified within the English charms corpus to be possibly extended to become the foundation of an international catalogue (Roper 2004: 139-140).

17 This is also why at the international conferences of the society there is an emerging tradition of having separate panels on certain well-known European types. The latest such panel was in May 2016 in Cork in the section Flum Jordan/Jordansegen, or earlier in 2011 in Moscow the panel on texts to heal fever (Fiebersegen).

18 Theo Meder, Dutch folktale researcher conducted the following experiment: five researchers were asked to identify the main motifs of one version of the Cinderella. The story contains 124 sentences and the researchers found a total of 68 minor and major motifs, which would suggest that there is a motif in at least every second sentence; 
moreover, what was even more surprising is that there were only three motifs that all researchers identified and considered essential: the cruel stepmother, the glass slipper, and the slipper test (Meder 2014: 123).

${ }^{19}$ In Hungarian folklore studies cf. the study by Ildikó Landgraf about the impossibility of classifying historical legends into types (Landgraf 2006).

${ }^{20}$ The first known texts of the Longinus charm are in Latin and in German, documented from the tenth century. Cf. Roper 2004: 130; HwdA: "Longinussegen". For English text see: Olsan 2004: 76-77; Roper 2005: 112-114.

${ }^{21}$ Pócs 2014b: 923. Éva Pócs still discusses this in a separate sub-type within narrative texts.

22 The Flum Jordan charms were used mostly to stop bleeding or to heal bleeding wounds; the text has been known from the twelfth century throughout Western and Eastern Europe as well, in both written and oral traditions. See Flum Jordan type developed for a possible international charm index in Agapkina \& Toporkov 2013: 89-91.

${ }^{23}$ Pócs 2014b: 713, 942. In the Hungarian material these motifs are mostly related to texts healing bewitchment. See, for instance, group XV of Hungarian charms where Jesus is bewitched and Virgin Mary or a saint heals him with the water of the River Jordan (Pócs 2014b: 809-855).

${ }^{24}$ Daiva Vaitkevičiene also points out that in her classification many texts could have been classified into at least two categories (Vaitkevičienè 2008: 85).

${ }^{25}$ For the overview and examples of the sub-type see Pócs 2014b: 895-914. According to Éva Pócs, this sub-type was diffused in the southern part of the Hungarian Great Plain and in Moldova, and she also knows about Italian, Romanian, Serbian and Croatian parallels, therefore she suspects that the text material had in the past spread over a wider Mediterranean and Central European region.

${ }^{26}$ Ohrt 1936a. For a short Hungarian overview of encounter charms and the related Hungarian texts see Pócs 2014b: 709-793.

${ }^{27}$ By 'well-known' Western European types I mostly mean the charm types that became known from the research carried out by Oskar Ebermann (1903), Ferdinand Ohrt $(1936 a, 1936 b, 1938)$ and other scholars in the first half of the twentieth century. See the charm type entries in the Handwörterbuch des deutschen Aberglaubens handbook (Hoffmann-Krayer \& Bächtold-Stäubli 1927-1942).

${ }^{28}$ The various uses of Historical-Geographic Method(s) in current folkloristic research has most recently been discussed in Frog's study (Frog 2013: 23-30).

29 This essentially contradicts what Honko had formulated on several occasions, namely that archival folklore texts are "dead artefacts" which had lost their meaning, however in 1986 Honko himself did not preclude the possibility of using archival materials as "dense" corpuses, but he was also calling attention to its difficulties (Honko 1986: 116; cf. Anttonen 2013: 159-161; Gunnell et al. 2013: 173). Anttonen stresses that meanings can be found and analysed contextually in archival folklore materials if we ask the right questions instead of making the archival materials accountable for the lack of information that only becomes relevant to future paradigms (cf. Anttonen 2013). 
The use of archival texts as a thick corpus is best modelled in the recent Finnish and Scandinavian historical folklore studies.

30 This is how Lauri Honko defined the three major textual paradigms of folklore studies (Honko 2000a: 5-14, 2000b: 6-18). John Foley gave a similar definition of textual paradigms with a detailed description of theories in the $60 \mathrm{~s}$ and $70 \mathrm{~s}$ that shaped the reconsideration of the problems and limits of folklore text editions, especially in Western European and American folklore studies. Foley considered three theories to be important: (1) the oral-formulaic theory of a research studying epic poetry at Harvard University; (2) the approaches of ethnography of speaking and ethnopoetics; (3) and performance studies (Foley [1995] 1997). In Hungarian, and in many cases in other European folkloristics, the above theories have not changed the previous practices of archiving and editing folklore texts, aside from a few pioneering attempts. Most of the European folklore archives continued to function, to this day, in the archiving system set up in the early-twentieth-century golden age of the Historical-Geographic Method(s) when folklore archives were established. See for instance: the comments of Fredrik Skott about Swedish archives at the Vilnius roundtable discussion (Gunnell et al. 2013: 199-200).

${ }^{31}$ In light of the changes in the textual procedures of folklore studies, including textual paradigm shifts, several authors point out that they mostly stem from the new technical options of recording and storing orality (Voigt 2006: 309-311; Katajamäki \& Lukin 2013: 11; Frog 2013: 23). Although computational procedures to analyse folklore texts have been conducted since the $60 \mathrm{~s}$ (see: Voigt 1981), the paradigm-shifting role and significance of technological developments related to computer science only became evident in the past 10-15 years with the appearance of the internet and the mass diffusion of online databases.

${ }^{32}$ See the programmatic overview of the objectives set by computational folkloristics, as a new disciplinary approach: Abello \& Broadwell \& Tangherlini 2012: 63.

${ }^{33}$ Cf. for instance: Niles 2013: 221.

${ }^{34}$ Within the framework of the present study there is no room to discuss concrete technical problems in detail. The digital folklore databases known today have used standardized developments of XML (Extensible Markup Language) and TEI (Text Encoding Initiative), which proved to be the most popular and long-lasting among the various markup-languages so far. See for instance Holger \& Schering \& Schmitt 2014. For Hungarian references see the comments of István Csörsz Rumen at the 2003 textual folkloristic roundtable discussion, where he outlined the opportunities of XML-based processing of popular poetry (Barna 2003: 67-72).

${ }^{35}$ According to Tangherlini, since the beginning of research the folkloristic 'equation' consists of connecting and interpreting the three main actors: people (storytellers and scholars), places (where stories were collected and mentioned in stories), and stories (or folkloric expression in general) (Tangherlini 2016: 65).

${ }^{36}$ See for instance the WossiDiA directed by Christoph Schmitt (Holger \& Schering \& Schmitt 2014: 69; Meder 2014; Tangherlini 2016: 66).

${ }^{37}$ Meder 2014: 124; Tangherlini 2013: 15-20. The limits of the applicability of typologies is also apparent where the basis of the database is the complete bequest of a prominent 
collector and not a specific genre, such as the WossiDiA (Holger \& Schering \& Schmitt 2014), or the ETKSpace and Danish Folklore Nexus (Tangherlini \& Broadwell 2014).

${ }^{38}$ About the various error types, the error ratio of manual annotation and the possibilities of automated annotation in relation to the Dutch folktale database see Muiser \& Theune \& Meder 2012; Meder \& Karsdorp \& Nguyen \& Theune \& Trieschnigg \& Muiser 2016: 82-87.

39 The 'top-down' and 'bottom-up' approaches termed by Timothy R. Tangherlini also cover these two types of annotation; cf. Abello \& Broadwell \& Tangherlini 2012.

40 There are countless initiatives within digital humanities (for instance: Dublin Core Metadata Initiative: DCMI, Open Archives Initiative Protocol for Metadata Harvesting: OAI-PMH, CLARIN) for the standardisation of these meta-data in hope of new exchanges (Meder 2014: 125).

${ }^{41}$ For instance: Meder 2014: 124; Katajamäki \& Lukin 2013: 13. See the objectives of the SIEF Working Group on Archives here: http://www.siefhome.org/wg/arch/.

42 Timothy R. Tangherlini introduces the term 'distant reading' into computational folkloristics research, borrowed from the literary scholar Franco Moretti (originally used for the study of literature). According to 'distant reading', and contrary to the former 'close reading', computer programs create the possibility of a wider/more distant reading in which the directions, the processes and the frameworks of the levels above and below the text, which otherwise would not be perceivable for the researcher, can be outlined. Cf. Tangherlini 2013: 10-11; Abello \& Broadwell \& Tangherlini 2012: 62.

${ }^{43} \mathrm{http} / / / \mathrm{cds}$.library.brown.edu/projects/romanianCharms/

44 The syntax of the markup-language can be reached at this link: http://cds.library.brown.edu/projects/romanianCharms/tagDoc.html\#markupsyntax

45 This problem in terms of nineteenth-century Hungarian folktale material was pointed out by Judit Gulyás (Gulyás 2012: 335). Timothy R. Tangherlini published the manuscripts of field notes, correspondence and finally the publication end product in the ETKNexus database processing the material of Evald Tang Kristensen (Tangherlini \& Broadwell 2014).

46 The international catalogue project of Jonathan Roper and Tatjana Agapkina and Andrei Toporkov is a good starting point for the definition of basic metadata (Roper 2004: 52-89, 2005; Agapkina \& Toporkov 2013: 82). For the basic metadata of the Dutch folktale database see: Muiser \& Theune \& Meder 2012.

${ }^{47}$ Such as the Finnish Runot database, which processed in a digital database 27,000 pages of the 34 volumes of Suomen Kansan Vanhat Runot (SKVR) published between 1908 and 1948. See: http://skvr.fi/

${ }^{48}$ For more detail see: Muiser \& Theune \& Meder 2012.

49 "Practicing computational humanities only makes sense if we develop questions that computers are better able to answer than are researchers.” (Meder \& Karsdorp \& Nguyen \& Theune \& Trieschnigg \& Muiser 2016: 93). 
${ }^{50}$ First published by Lajos Kálmány in the late 19th century from Egyházaskér (Pócs 2014b: 896).

${ }^{51}$ From a witch trial (1752, Pécs) (Ilyefalvi 2014b: 203-204).

${ }^{52}$ Collected by Zoltán Polner in 1976 from Királyhegyes (Pócs 2014b: 900).

${ }^{53}$ Collected by Zoltán Polner in 1976 from Szốreg (Pócs 2014b: 907).

${ }^{54}$ Collected by Zoltán Polner in 1973 from Tápé (Pócs 2014b: 907-908).

${ }^{55}$ Collected by Lajos Balázs in 1999 from Csíkszentdomokos (Pócs 2014b: 672-673).

${ }^{56}$ First published by Áron Szilády in the late 19th century (Pócs 2014b: 698).

${ }^{57}$ Collected by Zsuzsanna Erdélyi in 1971 from Felsônána (but informant were resettled from Hadikfalva (Dorneşti), Romania) (Pócs 2014b: 732-733).

\section{REFERENCES}

Abello, James \& Broadwell, Peter \& Tangherlini, Timothy R. 2012. Computational Folkloristics. Communications of the ACM, 55(7), pp. 60-70. https://doi.org/10.1145/2209249.2209267

Agapkina, Tatiana A. \& Levskievskaja, Elena E. \& Toporkov, Andrei L. 2003. Polesskije zagovory zapisah v 1970-1990-h. gg. Moskva: Indrik.

Agapkina, Tatiana \& Toporkov, Andrei L. 2013. Charm, indexes: Problems and Perspectives. In: James A. Kapaló, Éva Pócs, William F. Ryan (eds.) The Power of Words. Studies on Charms and Charming in Europe. Budapest: Central European University Press, pp. 71-99.

http://www.jstor.org/stable/10.7829/j.ctt2tt29w

Anttonen, Pertti 2013. Lost in Intersemiotic Translation? The Problem of Context in Folk Narratives in the Archive. In: Arne Bugge Amundsen (ed.) ARV. Nordic Year Book of Folklore, 69, pp. 153-170.

Barna, Gábor (ed.) 2003. Történeti források és jelenkori folklórszövegek lejegyzésének, átírásának és kiadásának kérdései. Szeged: SzTE Néprajzi-Kulturális Antropológiai Tanszék.

Borsje J. 2011. Digitizing Irish and Dutch charms. In: Tatyana A. Mikhailova, Jonathan Roper, Andrey L. Toporkov, Dmitry S. Nikolayev (eds.) Oral Charms in Structural and Comparative Light. Moscow: PROBEL, pp. 128-137.

Bozóky, Edina 2003. Charmes et prières apotropaïques. (Typologie des sources du Moyen Âge occidental, 86.) Brepols: Turnhout.

Braekman, Willy Louis 1997. Middeleeuwse witte en zwarte magie in het Nederlands taalgebied: gecommentarieerd compendium van incantamenta tot einde 16de eeuw. (Reeks VI.) Gent: Koninklijke Academie voor Nederlandse Taal- en Letterkunde.

Briggs, Charles L. 1993. Metadiscursive Practices and Scholarly Authority in Folkloristics. The Journal of American Folklore, 106(422), pp. 387-434. http://doi.org/10.2307/541905 
Dégh, Linda 1986. Introduction: Special Double Issue. The Comparative Method in Folklore. Journal of Folklore Research, 23(2-3), pp. 77-85. http://www.jstor.org/stable/3814441

Ebermann, Oskar 1903. Blut- und Wundsegen in ihrer Entwicklung dargestellt. (Palaestra XXIV.) Berlin: Mayer und Müller.

Fine, Elizabeth C. 1984. The Folklore Text: From Performance to Print. Bloomington: Indiana University Press.

Foley, John Miles 1997 [1995]. Folk Literature. In: D. C. Greetham (ed.) Scholarly Editing: A Guide to Research. New York: The Modern Language Association of America, pp. 600-626.

Frog 2013. Revisiting the Historical-Geographic Method(s). RMN Newsletter 7. Special issue: Limited Sources, Boundless Possibilities Textual Scholarship and the Challenges of Oral and Written Texts, pp. 18-34.

http://www.helsinki.fi/folkloristiikka/English/RMN/RMN_7_Dec_2013_Limited_ Sources_Boundless_Possibilities.pdf

Gay, David E. 2000. Inventing the Text: A Critique of Folklore Editing. Folklore: Electronic Journal of Folklore, 14, pp. 98-117.

https://doi.org/10.7592/FEJF2000.14.editing

Golopenţia, Sanda 1997. Mapping a Network of Semiotic Systems: The Romanian Love Charms Database. Semiotica, 114(1-2), pp. 41-66.

https://doi.org/10.1515/semi.1997.114.1-2.41

Golopenţia, Sanda 1998. Desire Machines: a Romanian Love Charms Database. Bucharest: The Publishing House of the Romanian Cultural Foundation.

Golopenţia, Sanda 2004. Towards a Typology of Romanian Love Charms. In: Jonathan Roper (ed.) Charms and Charming in Europe. Hampshire-New York: Palgrave Macmillan, pp. 145-187.

https://doi.org/10.1057/9780230524316

Gunnell, Terry et alii 2013. Discussion. Why Should Folklore Students Study “Dead” Legends? (A Round-Table Discussion Held at the 16th Congress of the, international Society for Folk Narrative Research in Vilnius, Lithuania, 29th June 2013.). In: Arne Bugge Amundsen (ed.) ARV. Nordic Year Book of Folklore, 69, pp. 171-209.

Gulyás, Judit 2012. A magyar történeti mesekutatás. Ethnographia, 123, pp. 317-343.

Hattyuffy, Dezsố 1891. Két régi babona. Századok, 25(6), pp. 501-504.

Hoffmann-Krayer, Eduard \& Bächtold-Stäubli, Hanns (eds.) 1927-42. Handwörterbuch des deutschen Aberglaubens. 1-10. Berlin-Leipzig: Walter de Gruyter.

Holger, Meyer \& Schmitt, Christoph \& Janssen, Stefanie \& Schering, Alf-Christian (eds.) 2014. Corpora ethnographica online: Strategien der Digitalisierung kultureller Archive und ihrer Präsentation im internet. (Rostocker Beiträge zur Volkskunde und Kulturgeschichte, 5.) Münster: Waxmann.

http://rosdok.uni-rostock.de/file/rosdok_document_0000005031/rosdok_derivate_0000019754/ceo2012.pdf

Holger, Meyer \& Schering, Alf-Christian \& Schmitt, Christoph 2014. WossiDiA - The Digital Wossidlo Archive. In: Holger, Meyer \& Schmitt, Christoph \& Janssen, Stefanie \& Schering, Alf-Christian (eds.) Corpora ethnographica online: Strategien der Digitalisierung kultureller Archive und ihrer Präsentation im, internet. 
(Rostocker Beiträge zur Volkskunde und Kulturgeschichte, 5.) Münster: Waxmann, pp. 61-85.

http://rosdok.uni-rostock.de/file/rosdok_document_0000005031/rosdok_derivate_0000019754/ceo2012.pdf

Holzmann, Verena 2001. "Ich beswer dich wurm und wyrmin..." Formen und Typen altdeutscher Zaubersprüche und Segen. Bern: Peter Lang.

Honko, Lauri 1986. Types of Comparison and Forms of Variation. Journal of Folklore Research, 23(2-3). Special Double Issue: The Comparative Method in Folklore, pp. 105-124. http://www.jstor.org/stable/3814443

Honko, Lauri 2000a. Text as Process and Practice: The Textualization of Oral Epics". In: Lauri Honko (ed.) The Textualization of Oral Epics. The Hague: Mouton, pp. 3-56.

Honko, Lauri 2000b. Thick Corpus, Organic Variation: an introduction. In: Lauri Honko (ed.) Thick Corpus, Organic Variation and Textuality in Oral Tradition. (Studia Fennica Folkloristica 7.) Helsinki: Finnish Literature Society, pp. 3-28.

Ilyefalvi, Emese 2014a. Bevezetô. In: Emese Ilyefalvi (ed.) Ráolvasások. Gyújtemény a történeti forrásokból (1488-1850). Budapest: Balassi Kiadó, pp. 11-37.

Ilyefalvi, Emese (ed.) 2014b. Ráolvasások. Gyújtemény a történeti forrásokból 1488-1850. (A magyar folklór szövegvilága 2/B). Budapest: Balassi Kiadó.

Jockers, Matthew L. \& Underwood, Ted 2016. Text Mining and the Humanities. In: Susan Schreibman, Raymond George Siemens, John Unsworth (eds.) A New Companion to Digital Humanities. (Revised edition.) (Blackwell Companions to Literature and Culture.) Chichester, West Sussex: Wiley Blackwell, pp. 291-306. https://doi.org/10.1002/9781118680605.ch20

Kapaló, James A. \& Pócs, Éva \& Ryan, William (eds.) 2013. The Power of Words: Studies on Charms and Charming in Europe. Budapest: Central European University Press. http://www.jstor.org/stable/10.7829/j.ctt2tt29w

Kapaló, James A. 2011a. Genre and Authority in the Genesis of Charm and Prayer, Incantatio, 1(1), pp. 79-101. https://doi.org/10.7592/Incantatio2011_1_Kapalo

Kapaló, James A. 2011b. Text, Context and Performance: Gagauz Folk Religion in Discourse and Practice. (Numen Book Series: Studies in the History of Religions, 135.) Leiden-Boston: Brill.

Katajamäki, Sakari \& Lukin, Karina 2013. Textual Trails from Oral to Written Sources: An Introduction. RMN Newsletter, 7. Special issue: Limited Sources, Boundless Possibilities Textual Scholarship and the Challenges of Oral and Written Texts, pp. 8-17.

http://www.helsinki.fi/folkloristiikka/English/RMN/RMN_7_Dec_2013_Limited_ Sources_Boundless_Possibilities.pdf

Kljaus, Vladimir 2009. On Systematizing the Narrative Elelments of Slavic Charms. In: Jonathan Roper (ed.) Charms, Charmers and Charming. International Research on Verbal Magic. Hampshire-New York: Palgrave Macmillan, pp. 71-86. https://doi.org/10.1057/9780230583535

Kõiva, Mare 2011. Eesti loitsud [Estonian Incanations]. Tartu: Pegasus. 
Kuznetsova, Ekaterina \& Toporkov, Andrey 2012. Conference Report. "Oral Charms in Structural and Comparative Light", International Conference at the Russian State University for the Humanities and at the Russian Academy of Sciences. Incantatio 2 , pp. 118-128.

https://10.7592/Incantatio2012_1_Reports

Landgraf, Ildikó 2006. Archívumon, innen, katalóguson túl. Többletek és hiányok a mai magyar történeti mondakutatás múfajelméleti és rendszerezési kérdéseiben. In: Mihály Hoppál, Gábor Vargyas (eds.) Ethno-lore, XXIII, pp. 27-40.

Lecouteux, Claude 1996. Charmes, Conjurations et Bénédictions - Lexique et formules. Paris: Honoré Champion.

Niles, John D. 2013a. Orality. In: Neil Fraistat, Julia Flanders (eds.) The Cambridge Companion to Textual Scholarship. (Cambridge Companions to Literature.) Cambridge: Cambridge University Press, pp. 215-223. https://doi.org/10.1017/CCO9781139044073

Niles, John D. 2013b. From Word to Print - and Beyond. Western Folklore, 72(3-4), pp. 229-251.

Meder, Theo 2014. The Folktale Database as a Digital Heritage Archive and as a Research Instrument. In: Meyer Holger, Christoph Schmitt, Stefanie Janssen, Alf-Christian Schering (eds.) Corpora ethnographica online: Strategien der Digitalisierung kultureller Archive und ihrer Präsentation im internet. (Rostocker Beiträge zur Volkskunde und Kulturgeschichte, 5). Münster: Waxmann, pp. 119-129.

http://rosdok.uni-rostock.de/file/rosdok_document_0000005031/rosdok_derivate_0000019754/ceo2012.pdf

Meder, Theo \& Karsdorp, Folgert \& Nguyen, Dong \& Theune, Mariët \& Trieschnigg, Dolf \& Muiser, Everhardus Iwe Christiaan 2016. Automatic Enrichment and Classification of Folktales in the Dutch Folktale Database. Journal of American Folklore, 129(511), pp. 78-96.

https://doi.org/10.5406/jamerfolk.129.511.0078

McGann, Jerome J. 2016. Marking Texts of Many Dimensions. In: Susan Schreibman, Raymond George Siemens, John Unsworth (eds.) A New Companion to Digital Humanities. (Revised edition.) (Blackwell Companions to Literature and Culture.) Chichester, West Sussex: Wiley Blackwell, pp. 358-376.

https://doi.org/10.1002/9781118680605

McGann, Jerome J. 2014. A New Republic of Letters: Memory and Scholarship in the Age of Digital Reproduction. Cambridge, Massachusetts: Harvard University Press.

Muiser, Iwe Everhardus Christiaan \& Theune, Mariët \& Meder, Theo 2012. Cleaning up and Standardizing a Folktale Corpus for Humanities Research. In: Francesco Mambrini, Marco Passarotti, Caroline Sporleder (eds.) Proceedings of the Second Workshop on Annotation of Corpora for Research in the Humanities (ACRH2). Lisboa: Edições Colibri, pp. 63-74.

Ohrt, Ferdinand 1936a. Über Alter und Ursprung der Begegnungssegen. Hessische Blätter für Volkskunde, 35, pp. 49-58.

Ohrt, Ferdinand 1936b. Segen. In: Eduard Hoffman-Krayer, Hanns Bächtold-Stäubli (eds.) Handwörterbuch des deutschen Aberglaubens. VII, pp. 1582-1620. BerlinLeipzig: Walter de Gruyter \& Co. 
Ohrt, Ferdinand 1938. Die ältesten Segen über Christi Taufe und Christi Tod in religionsgeschichtlichem Lichte. (Historisk-filologiske Meddelelser, XXV. 1.) København: Levin \& Munksgaard.

Olsan, Lea 2004. Charms in Medieval Memory. In: Jonathan Roper (ed.) Charms and Charming in Europe. Hampshire-New York: Palgrave Macmillan, pp. 59-88. https://doi.org/10.1057/9780230524316

Pócs, Éva 2014a. Bevezetô. In: Éva Pócs (ed.) Ráolvasások. Gyújtemény a legújabb korból (1851-2012). (A magyar folklór szövegvilága 2/A.) Budapest: Balassi Kiadó, pp. $13-42$.

Pócs, Éva (ed.) 2014b. Ráolvasások. Gyújtemény a legújabb korból 1851-2012. (A magyar folklór szövegvilága 2/A.) Budapest: Balassi Kiadó.

Roper, Jonathan 2004. Typologising English Charms. In: Jonathan Roper (ed.) Charms and Charming in Europe. Hampshire-New York: Palgrave Macmillan, pp. 128144. https://doi.org/10.1057/9780230524316

Roper, Jonathan 2005. English Verbal Charms. (Folklore Fellows' Communications, 288.) Helsinki: Academia Scientiarum Fennica.

Roper, Jonathann (ed.) 2004. Charms and Charming in Europe. Hampshire-New York: Palgrave Macmillan. https://doi.org/10.1057/9780230524316

Roper, Jonathan (ed.) 2009. Charms, Charmers and Charming. International Research on Verbal Magic. Hampshire-New York: Palgrave Macmillan. https://doi.org/10.1057/9780230583535

Sebeok, A. Thomas 1974. Charms. Structure and texture: selected essays in Cheremis verbal art. (De proprietatibus litterarum Ser. practica), Mouton: The Hague, pp. $14-41$.

Siikala, Anna-Leena 1986. Variation in the Incantation and Mythical Thinking: The Scope of Comparative Research. Journal of Folklore Research, 23(2-3), pp. 187204. http://www.jstor.org/stable/3814448

Schulz, Monika 2003. Beschwörungen im Mittelalter. Einführung und Überblick. Heidelberg: Universitätsverlag C. Winter.

Stiùbhart, Domhnall Uilleam 2013. The Making of a Charm Collector. Alexander Carmichael in Uist, from 1864 to 1882. In: James A. Kapaló, Éva Pócs, William F. Ryan (eds.) The Power of Words. Studies on Charms and Charming, in Europe. Budapest: Central European University Press, pp. 27-70. http://www.jstor.org/stable/10.7829/j.ctt2tt29w

Szilágyi, Márton 2014. Textológia, filológia, értelmezés. In: Mariann Czifra, Márton Szilágyi (eds.) Textológia, filológia, értelmezés: klasszikus magyar irodalom. (Csokonai könyvtár: bibliotheca studiorum litterarium, 55.) Debrecen: Debreceni Egyetemi Kiadó, pp. 15-25.

Takács, György 2015. Elindula boldogságos szép Szüz Mária. Ráolvasók a régi Csíkszékéról. (Fontes Ethnologiae Hungaricae X.) Budapest-Pécs: L’HarmattanPTE Néprajz-Kulturális Antropológia Tanszék.

Tangherlini, Timothy R. 2013. The Folklore Macroscope. Western Folklore 72(1), pp. 7-27. 
Tangherlini, Timothy R. 2016. Big Folklore: A Special Issue on Computational Folkloristics. Journal of American Folklore, 129(511), pp. 5-13.

https://doi.org/10.5406/jamerfolk.129.511.0005

Tangherlini, Timothy R. \& Broadwell, Peter M. 2014. Sites of (re)Collection: Creating the Danish Folklore Nexus. Journal of Folklore Research, 51(2), pp. 223-247. https://doi.org/10.2979/jfolkrese.51.2.223

Timotin, Emanuela 2010. Descântecele manuscrise româneşti (secolele al XVII-lea - al XIX-lea). Bukarest: Editura Academiei Române.

Toporkov, Andrey L. 2005. Zagovory v russkoj rukopisnoj tradicii XV-XIX vv: istorija, simvolika, poètika. Tradicionnaja duchovnaja kul'tura slavjan: Sovremennye issledovanija. Moskva: Izdat.

Toporkov, Andrey L. 2010. Russkije zagovory iz rukopisnyh istočnikov XVI-pervoi poloviny XIX. vv. Istorija, simbolika, poetika. Moskva: Indrik.

Vaitkevičienè, Daiva 2008. Lietuviu užkalbejjimai: gydymo formulés. Lithuanian Verbal Healing Charms. Vilnius: Lietuvių Literatūros ir Tautosakas Institùtas.

Virtanen, Leea 1993. Is There the Comparative Method Out of Date? In: Michael Chesnutt (ed.) Telling Reality. Folklore Studies in Memory of Bengt Holbek. (NIF Publications 26.) Copenhagen \& Turku: Department of Folklore, University of Copenhagen, pp. 255-272.

Voigt, Vilmos 1981. Computertechnik und -analyse. In: Kurt Ranke (ed.) Enzyklopädie des Märchens Handwörterbuch zur historischen und vergleichenden Erzählforschung. Vol. 3. Berlin-New York: Walter de Gruyter, pp. 111-123.

Voigt, Vilmos 2004. A magyar folklór textológia helyzete és új távlatai. Irodalomtörténet, 85, pp. 356-366.

Voigt, Vilmos 2006. The Theory of Database in Folk Narrative Studies. Fabula, 47, pp. 308-318.

Voigt, Vilmos \& Balogh, Lajos 1974. A népköltési (folklór) alkotások kritikai kiadásának szabályzata. Budapest: Akadémiai Kiadó.

Wolf-Knuts, Ulrika 2000. On the History of Comparison in Folklore Studies. In: Lauri Honko (ed.) Thick Corpus, Organic Variation and Textuality in Oral Tradition. (Studia Fennica Folkloristica 7.) Helsinki: Finnish Literature Society, pp. 254283.

Wynne, Martin 2012. Do we need annotated corpora in the era of the data deluge? (Keynote abstract.). In: Francesco Mambrini, Marco Passarotti, Caroline Sporleder (eds.) Proceedings of the Second Workshop on Annotation of Corpora for Research in the Humanities (ACRH2). Lisboa: Edições Colibri, pp. 1-2. 
ISNFR Committee on

Charms, Charmers and Charming

\section{Incantatio}

An International Journal on

Charms, Charmers and Charming

\section{Issue 6}

Editors: James Kapaló and Jenny Butler

Tartu 2017 
General Editor: Mare Kõiva

Editors for this issue: James Kapaló and Jenny Butler

Copy editor: Liisa Vesik

Language editor: Jonathan Roper

Editorial board:

Elenora Cianci, University of Chieti- Pescara, Italy

James Kapalo, University College Cork, Ireland

Alaric Hall, Leeds University, UK

Claude Lecouteux, Paris-Sorbonne University, France

Lea Olsan, University of Louisiana at Monroe, USA

Éva Pócs, Janus Pannonius University, Pecs, Hungary

Haralampos Passalis, Intercultural School-Evosmos-Thessaloniki, Greece

Jonathan Roper, Tartu University, Estonia

Will Ryan, The Folklore Society, London, UK.

Emanuela Timotin, Institute of Linguistics, Bucharest, Romania

Andrey Toporkov, Institute of World Literature, Moscow, Russia

Daiva Vaitkevičiene, Lithuanian Institute of Literature and Folklore, Vilnius, Lihtuania

Editorial contacts:

http://www.foklore.ee/incantatio

incantatio@folklore.ee

Vanemuise 42, Tartu 51003, Estonia

Supported by and affiliated to the Centre of Excellence in Estonian Studies (CEES, European Regional Development Fund) and is related to research projects IRG 22-5 (Estonian Research Council) and EKKM14-344 (Estonian Ministry of Education and Research).

Indexed by

the MLA Directory of Periodicals (EBSCO), Central and Eastern European Online Library (C.E.E.O.L.), Open Folklore Project.

Copyright belongs to the authors and the ISFNR Committee on Charms, Charmers and Charming

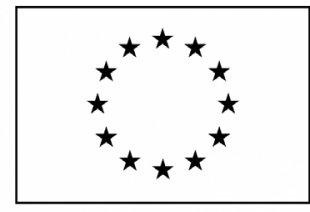

European Union European Regional Development Fund

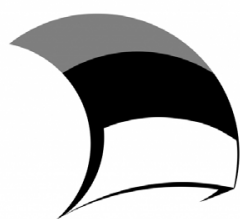

Investing in your future

ISSN 2228-1355

https://doi.org/10.7592/Incantatio 
http://www.folklore.ee/incantatio

https://doi.org/10.7592/Incantatio

https://doi.org/10.7592/Incantatio2017_6

\section{Contents}

Introduction

https://doi.org/10.7592/Incantatio2017_6_Introduction

James Kapaló and Jenny Butler

Charms and the Divining Rod:

Tradition and Innovation in Magic and

Pseudo-Science, 15th to 21st Centuries

https://doi.org/10.7592/Incantatio2017_6_Dillinger

Johannes Dillinger

Dealing with Danger: The Practices of Keeping and 24

Discarding Magical Letters

https://doi.org/10.7592/Incantatio2017_6_Radchenko

Daria Radchenko

Textualization Strategies, Typological Attempts,

Digital Databases: What is the Future of

the Comparative Charm Scholarchip?

https://doi.org/10.7592/Incantatio2017_6_llyefalvi

Emese Ilyefalvi 
The Terrors of the Night:

Charms against the Nightmare and the Mythology of Dreams https://doi.org/10.7592/Incantatio2017_6_Milne Louise S. Milne

A Shared Inheritance: The Interrelationship between Divination and Charming in 21st Century Canada https://doi.org/10.7592/Incantatio2017_6_Sawden Kari Sawden

Threefold Stories, Threefold Charms:

Bécquer's Poetic Ethnography of Witchcraft https://doi.org/10.7592/Incantatio2017_6_Tausiet

María Tausiet

Seeking Voices and Finding Meaning:

An Analysis of Portuguese Verbal Divination https://doi.org/10.7592/Incantatio2017_6_Levitao José Vieira Leitão

https://doi.org/10.7592/Incantatio2017_6_Reports

"Charms, Charmers and Charming:

Innovation and Tradition"

(May 6-8, 2016, University College Cork, Ireland) 